POLYGLOT JOYCE: FICTIONS OF TRANSLATION 
This page intentionally left blank 


\section{Patrick O'Neill}

\section{Polyglot Joyce}

Fictions of Translation 
www.utppublishing.com

(C) University of Toronto Press Incorporated 2005

Toronto Buffalo London

Printed in Canada

ISBN 0-8020-3897-2

(6)

Printed on acid-free paper

\section{Library and Archives Canada Cataloguing in Publication}

O'Neill, Patrick, 1945-

Polyglot Joyce : fictions of translation / Patrick O'Neill

Includes bibliographical references and index.

ISBN 0-8020-3897-2

1. Joyce, James, 1882-1941 - Translations. 2. Joyce, James, 1882-1941 - Translations - History and criticism. I. Title.

PR6019.09Z7812 $2005 \quad 823^{\prime} .912 \quad$ C2005-900956-X

University of Toronto Press acknowledges the financial assistance to its publishing program of the Canada Council for the Arts and the Ontario Arts Council.

This book has been published with the help of a grant from the Canadian Federation for the Humanities and Social Sciences, through the Aid to Scholarly Publications Programme, using funds provided by the Social Sciences and Humanities Research Council of Canada.

University of Toronto Press acknowledges the financial support for its publishing activities of the Government of Canada through the Book Publishing Industry Development Program (BPIDP). 
For Trudi,

who also shares a birthday

with Molly Bloom 
This page intentionally left blank 